Oral Section

\title{
Search for a molecular mechanism of action of the potentized homeopathic drugs in living organisms
}

\author{
Anisur Rahman Khuda-Bukhsh \\ Cytogenetics and Molecular Biology Laboratory, University of Kalyani, India
}

\begin{abstract}
The mechanism of action of the potentized homeopathic drugs, particularly those diluted beyond Avogadro's limit, is still a debatable issue and various hypotheses in this regard have been advocated by many. In our studies since 1980, we found that certain ultra-highly diluted homeopathic remedies could produce ameliorative effects in various model test organisms like bacteria, fungus, mice and human beings, while the succussed alcohol (placebo) could not. These drugs could antagonize/ameliorate several types of experimentally induced tumors/cancers in mice as evident from electron microscopic studies and certain specific cancer biomarkers. They also demonstrated significant effect on cell viability and apoptotic effect (mostly mitochondria mediated) on cancer cells in culture (also in experimental mice), as revealed from various assays like AnnexinV-FITC, TUNEL, DNA fragmentation, DAPI, COMET, HOECHST 33258, Rhodamine 123 etc while the succussed alcohol ("vehicle") failed to show such effect. Expression of some key signal proteins and mRNA expressions like Bcl2 family proteins, Cytochrome c, Apaf 1, PARP, Caspase family, p53 and p38 etc in experimental mice model could be modulated by potentized homeopathic drugs. Under arsenic stress, the bacterium Escherichia coli, and the fungus Saccharomyces cerevisiae, and macrophage cells in culture responded favorably to the treatment of potentized homeopathic drug, Arsenicum Album 30C and homeopathically prepared Glucose 30C, as evident from modulation of several parameters like ROS accumulation, SOD activity, lipid peroxidation and expression level of certain relevant genes (Ars B, pts-G genes using real-time PCR) denoting detoxification, mainly via arsenic removal mechanism and suitable enzymatic modulation. Ultra-highly diluted potentized drugs (at potency 30C or above) could demonstrate protective changes simultaneously in multiple parameters (most of them under genetic control) of study, and their action continued for sometime even after the drugs were withdrawn; this indicates the ability of the drugs to trigger "gene action" involving up-regulation or down-regulation of a cascade of downstream genes, getting the recovery process into motion. The convincing evidences that support a "gene regulatory hypothesis" to explain the molecular mechanisms of action of the potentized drugs will be discussed in the light of some of our recent experimental findings on fungus, bacteria and bacteriophages.
\end{abstract}

Keywords: homeopathy, ultra-high dilutions; molecular mechanism; gene expressions; signal proteins; in vivo, in vitro and microbial studies.

\section{(c)) EY-NC-ND Licensed to GIRI}

Support: The author did not receive funding for this study.

Conflict of interest: The author has no conflict of interest to declare.

Received: 01 June 2012; Revised: 08 August 2012; Published: 30 September 2012.

Correspondence author: Anisur Rahman Khuda-Bukhsh, khudabukhsh_48@rediffmail.com .

How to cite this article: Khuda-Buksh AR. Search for a molecular mechanism of action of the potentized homeopathic drugs in living organisms. Int J High Dilution Res [online]. 2012 [cited YYYY Month dd]; 11(40):147-147. Proceedings of the XXVI GIRI Symposium; 2012 Sep 20-22; Florence (Italy). GIRI; 2012; Available from: http://www.feg.unesp.br/ ojs/index.php/ijhdr/article/view/567/574 